\title{
Biological Control to Protect Watermelon Blossoms and Seed from Infection by Acidovorax avenae subsp. citrulli
}

\author{
A. Fessehaie and R. R. Walcott
}

Department of Plant Pathology, 4315 Miller Plant Sciences, The University of Georgia, Athens 30602. Accepted for publication 14 December 2004.

\begin{abstract}
Fessehaie, A., and Walcott, R. R. 2005. Biological control to protect watermelon blossoms and seed from infection by Acidovorax avenae subsp. citrulli. Phytopathology 95:413-419.

The efficacy of biological control seed treatments with Pseudomonas fluorescens (A506), Acidovorax avenae subsp. avenae (AAA 99-2), and an unidentified gram-positive bacterium recovered from watermelon seed (WS-1) was evaluated for the management of bacterial fruit blotch (BFB) of watermelon. In growth chamber and greenhouse experiments, seed treated with AAA 99-2 displayed superior disease suppression, reducing

melon blossom protection reduced seed infestation by A. avenae subsp. citrulli. From blossoms treated with $0.1 \mathrm{M}$ phosphate buffered saline (PBS), 63\% of the resulting seed lots were infested with A. avenae subsp. citrulli. In contrast, for blossoms protected with WS-1, Kocide, $P$. fluorescens A506, and AAA 99-2, the proportion of infested seed lots were 48.3, $21.1,24.1$, and $13.8 \%$, respectively. The effect of blossom treatments on seed lot infestation was statistically significant $(P=0.001)$ but WS-1 was not significantly different from PBS. These findings suggest that blossom protection with biological control agents could be a feasible option for managing BFB.
\end{abstract} BFB transmission by $96.5 \%$. AAA 99-2, P. fluorescens A506, and Kocide also suppressed the epiphytic growth of A. avenae subsp. citrulli when applied to attached watermelon blossoms $5 \mathrm{~h}$ prior to inoculation. Water-
Additional keywords: flowers, ovaries.
Bacterial fruit blotch of cucurbits (BFB) (Citrullus lanatus (Thunb.) Matsum \& Nakai), caused by Acidovorax avenae subsp. citrulli (Willems et al.) (Schaad et al.) $(25,32)$, is a devastating disease of cucurbits that was first reported in commercial watermelon production fields in Florida in 1989 (26). Since then, the pathogen has been a significant threat to U.S. and global cucurbit production (24). A. avenae subsp. citrulli-infested cucurbit seed represent the most important inoculum source and there is zero tolerance for the pathogen in seed and transplant production systems (8). In the early 1990s, BFB not only caused significant economic losses but, due to the legal liability to seed producers, it also resulted in the restriction of watermelon seed sale in certain "high-risk" states (16). Although the frequency of BFB outbreaks in commercial fruit production fields has declined, seed producers are continuously faced with the challenge of ensuring that seed lots are A. avenae subsp. citrulli free. To combat BFB, seed producers use A. avenae subsp. citrulli-free stock seed to produce seed crops in regions with cool, dry climates. Additionally, only seed from visually inspected, BFB-free fields are used for commercial production. Despite attempts to exclude infested seed, 1999 and 2000 were record years for BFB outbreaks in the United States (30).

One strategy that has been employed to improve BFB management is chemical seed treatment. Attempts to eliminate seedborne A. avenae subsp. citrulli have included fermentation and treatments with peroxyacetic acid, mercury chloride, streptomycin sulfate, and sodium hypochlorite $(7,9,27)$. In general, these treatments reduce but fail to eliminate seedborne A. avenae subsp. citrulli. Watermelons increasingly are being produced via transplants in high disease pressure environments; therefore, seed lots with low levels of infestation still present a significant BFB threat.

Corresponding author: R. R. Walcott; E-mail address: rwalcott@uga.edu

DOI: $10.1094 /$ PHYTO-95-0413

(C) 2005 The American Phytopathological Society
One ecologically sound approach that has not been explored for BFB management is biological control. Biological control seed treatment has been reported to reduce disease and improve seed germination $(6,10)$. Mao et al. (18) and Mew et al. (20) reported that biological control seed treatment reduced maize seed rot and seedling damping-off and rice sheath blight, respectively.

Another possibility for BFB management is protection of female watermelon blossoms from colonization by A. avenae subsp. citrulli. Recently, Walcott et al. (30) demonstrated that female watermelon blossoms could be sites of ingress for seed infestation by $A$. avenae subsp. citrulli. Under greenhouse conditions, inoculation of female watermelon blossoms resulted in the production of $A$. avenae subsp. citrulli-infested seed within asymptomatic fruit. While the significance of blossom colonization in BFB epidemiology remains to be determined, studies on fire blight have shown that pear and apple flowers are common infection courts for Erwinia amylovora (21). Biocontrol of fire blight has been demonstrated by applying antagonistic bacteria to apple and pear flowers prior to inoculation with $E$. amylovora $(11,17)$. To date, this approach has not been attempted for BFB management; hence, the objective of this study was to provide proof for the concept that blossom protection could prevent seed infestation by A. avenae subsp. citrulli. The specific objectives were to (i) identify effective candidate organisms for biological control of BFB and (ii) evaluate the efficacy of chemical or biological blossom protection for preventing seed infestation by $A$. avenae subsp. citrulli.

\section{MATERIALS AND METHODS}

Bacteria. A. avenae subsp. citrulli strains used in this study are listed in Table 1. Strains were routinely grown on King's medium B (KMB) (14) or nutrient agar (NA) (Beckton-Dickinson, Sparks, MD) for $48 \mathrm{~h}$ at $28^{\circ} \mathrm{C}$. To prepare inoculum, nutrient broth was inoculated with a single colony of each strain and incubated overnight at $30^{\circ} \mathrm{C}$ on a rotary shaker (Innova; New Brunswick 
Scientific Co., Edison, NJ) at $250 \mathrm{rpm}$. Bacterial concentration was determined spectrophometrically (Spectronic 20; Bausch and Lomb, Rochester, NY) (optical density at $600 \mathrm{~nm}=0.3$; $\approx 10^{8} \mathrm{CFU} / \mathrm{ml}$ ) and adjusted to the desired final concentration with sterile $0.1 \mathrm{M}$ phosphate buffered saline (PBS). All strains used in this study were stored in $15 \%$ glycerol at $-80^{\circ} \mathrm{C}$.

Selection and characterization of biocontrol candidates. Thirty bacteria, including previously reported biological control agents and several phytopathogenic and nonphytopathogenic Acidovorax sp. (Table 2), were screened for their ability to inhibit A. avenae subsp. citrulli growth using a technique previously described by Mercier and Lindow (19). Briefly, the biocontrol candidates were individually spotted on KMB or NA plates and incubated at $28^{\circ} \mathrm{C}$ for $48 \mathrm{~h}$. Suspensions containing $\approx 1 \times 10^{8}$ A. avenae subsp. citrulli $\mathrm{CFU} / \mathrm{ml}$ then were sprayed onto the plates, which were incubated for an additional $48 \mathrm{~h}$ at $28^{\circ} \mathrm{C}$. The appearance of zones of $A$. avenae subsp. citrulli growth inhibition was used to select potential biological control candidates (Fig. 1). Unidentified biocontrol candidates were characterized preliminarily by analysis of sole carbon source utilization profiles (BIOLOG, Hayward, CA).

Efficacy of biocontrol seed treatments under growth chamber conditions. Seed were obtained from BFB-infected watermelon fruit collected from a natural outbreak in Dodge County, GA in June 2003. After extraction, seed were air dried at $25^{\circ} \mathrm{C}$ overnight, pooled, and stored in paper bags at $5^{\circ} \mathrm{C}$ until they were used. Seed infestation was determined by immunomagnetic separation and the polymerase chain reaction (IMS-PCR) and by the seedling grow-out assay as previously described $(29,30)$. To assess the in vivo efficacy of the biocontrol candidates to suppress BFB seedling transmission, naturally infested seed samples $(n=$ 25 seed) were vacuum-infiltrated with each biocontrol agent. Briefly, seed were incubated in $25 \mathrm{ml}$ of cell suspension containing $\approx 1 \times 10^{8} \mathrm{CFU} / \mathrm{ml}$ of each biocontrol agent under a continuous vacuum for $20 \mathrm{~min}$. This allowed bacterial cells to be deposited under the seed coats. Treated seed were air-dried overnight at $25^{\circ} \mathrm{C}$ and assayed for BFB seedling transmission by the seedling grow-out assay. Seed were incubated in transparent plastic boxes (34 $\mathrm{cm}$ long by $24 \mathrm{~cm}$ wide by $6 \mathrm{~cm}$ high) (Tri-State Plastics, Dixon, KY) on two layers of blotter paper (Hoffman Manufacturing, Albany, OR), saturated with sterile water, under conditions of $>90 \%$ relative humidity $(\mathrm{RH}), 30^{\circ} \mathrm{C}$, and continuous fluorescent light. Seed treated with PBS in a similar manner served as a

TABLE 1. List of pathogenic Acidovorax avenae subsp. citrulli strains used in this study

\begin{tabular}{lcccc}
\hline Bacteria & Host & Year isolated & Source & Reference \\
\hline AAC00-1 & Watermelon & 1990 & R. Gitaitis & 31 \\
AAC94-48 & Watermelon & 1994 & R. Gitaitis & 31 \\
AAC8-1 ST & Watermelon & 2002 & R. Walcott & 30 \\
\hline
\end{tabular}

positive control. Seedling germination and BFB incidence were recorded daily for 15 days, starting 3 days after planting. Seed were considered to be germinated when an emerging radicle was visible. To reduce the risk of plant-to-plant contamination within germination boxes, seedlings were watered only as needed, and care was taken to prevent splash dispersal of bacteria by gently applying water directly to the edges of the blotter paper. Each treatment was replicated four times and the experiment was repeated twice. Mean germination percentage and mean BFB incidence data were plotted against time, and area under the disease progress curve (AUDPC) and area under the growth progress curve (AUGPC) values were calculated. Statistical analyses of the results were performed with SAS (version 8.0 for Windows; SAS Institute Inc., Cary, NC). The generalized linear model procedure was used to determine the significance of the effects of the biocontrol agents on BFB transmission and seed germination. Additionally, Fisher's protected test of least significant difference (LSD) was used to compare the effects of different biocontrol agents on BFB transmission and seed germination.

Efficacy of biocontrol seed treatments under greenhouse conditions. Samples ( $n=100$ seed/treatment) of watermelon cv. Crimson Sweet (Rogers NK, Boise, ID) were artificially inoculated by vacuum-infiltration in $50 \mathrm{ml}$ of a cell suspension containing $\approx 1 \times 10^{8} \mathrm{AAC00}-1 \mathrm{CFU} / \mathrm{ml}$ for $20 \mathrm{~min}$. Seed were air-dried overnight at $25^{\circ} \mathrm{C}$ on paper towels, and subsequently vacuuminfiltrated with biocontrol agents as described previously. In this study, seed treated in a similar manner with PBS and Kocide 101 (Griffin Corporation LLC, Valdosta, GA) (0.4\% wt/vol) served as positive and negative controls, respectively. Seed were air-dried

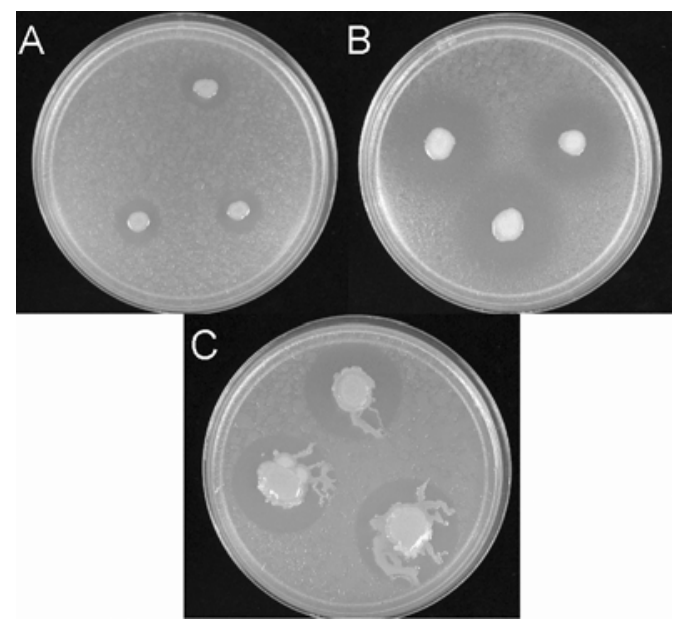

Fig. 1. Zones of growth inhibition for Acidovorax avenae subsp. citrulli on King's B medium induced by A, A. avenae subsp. avenae AAA99-2, B, Pseudomonas fluorescens A506, and C, WS-1, a gram-positive bacterium, tentatively identified as a Brevibacterium sp.

TABLE 2. Bacterial isolates screened for in vitro antagonistic activity against Acidovorax avenae subsp. citrulli

\begin{tabular}{|c|c|c|c|c|c|}
\hline Bacterium & Strains & Year isolated & Source & Geographical origin & Reference \\
\hline A. avenae subsp. citrulli (nonpathogenic) & ATCC29625 & 1970 & American Type Culture Collection & Georgia & 25 \\
\hline A. konjaci & $\ldots$ & $\ldots$ & R. Stall (pathogen) & Florida & 29 \\
\hline A. avenae avenae & AAA 78-1 & 1978 & R. Gitaitis (maize pathogen) & Georgia & This study \\
\hline A. avenae avenae & AAA $81-1$ & 1981 & R. Gitaitis (maize pathogen) & Georgia & This study \\
\hline A. avenae avenae & AAA 99-2 & 1999 & R. Gitaitis (maize pathogen) & Georgia & This study \\
\hline A. facilis & AF94-1 & 1994 & R. Gitaitis & Georgia & 29 \\
\hline Comomonas testosteronii & $\ldots$ & $\ldots$ & R. Stall & Florida & 29 \\
\hline Herbaspirillum rubisubalbicans & $\ldots$ & $\ldots$ & R. Gitaitis & Georgia & This study \\
\hline Pseudomonas fluorescens & A506 & 1993 & S. Lindow & California & 34 \\
\hline Burkholderia cepacia & BC11 & $\ldots$ & M. Schell & $\ldots$ & 12 \\
\hline Brevibacterium sp. & WS-1 & 2003 & A. Fessehaie (watermelon) & Georgia & This study \\
\hline Unidentified & WS-2 - 10 & 2003 & A. Fessehaie (watermelon) & Georgia & This study \\
\hline Flavimonas sp. & BCM202-1 & 1002 & F. Medeiros (cantaloupe) & Georgia & This study \\
\hline Unidentified & BCM202-2 - 202-10 & 2002 & F. Medeiros (cantaloupe) & Georgia & This study \\
\hline
\end{tabular}


overnight at $25^{\circ} \mathrm{C}$ and planted in 72-place polystyrene flats (Speedling Inc., Sun City, FL) in a commercial potting soil (Premiere Pro-Mix; Premier Horticulture Ltd., Quakertown, PA) under plastic chambers ( $32 \mathrm{~m}$ long by $4 \mathrm{~m}$ wide by $1.5 \mathrm{~m}$ high) that generated conditions of $32^{\circ} \mathrm{C}$ and $\approx 80 \% \mathrm{RH}$. To limit crosscontamination, seedlings were irrigated as needed, and care was taken to avoid cross-contamination by applying water at low pressure to plastic sheets on which the flats were resting. An experimental unit for this study was 72 seed and each treatment was replicated four times. Treatments were arranged in a randomized complete block design and the experiment was conducted three times. Seedling emergence and BFB seedling transmission data were collected daily for 21 days starting at day 5 . These data were plotted against time and used to generate mean AUDPC and AUGPC values for each treatment. Analysis of variance (ANOVA) was used to determine the significance of the differences among the effects of the seed treatments on AUGPC and AUDPC values generated from seedling emergence and BFB incidence data, respectively. Additionally, Fisher's LSD was used to compare the treatment effects on the mean AUDPC and AUGPC values.

Effects of biocontrol agents on $A$. avenae subsp. citrulli colonization of female watermelon blossoms. Watermelon plants (cv. Crimson Sweet) were established in 15-liter plastic pots under greenhouse conditions, as described previously (30). At anthesis, female watermelon blossoms, each on a separate plant, were pollinated and inoculated with AAA 99-2 or Pseudomonas fluorescens A506 at $\approx 1 \times 10^{9} \mathrm{CFU} /$ blossom. Additionally, $10 \mu \mathrm{l}$ of PBS and $10 \mu \mathrm{l}$ of Kocide $101(0.4 \% \mathrm{wt} / \mathrm{vol})$ were applied to blossoms as positive and negative controls, respectively. Five hours after treatment, each blossom was challenged with a kanamycin-resistant, constitutive green fluorescent protein (GFP) mutant of $A$. avenae subsp. citrulli, AAC8-1ST (30) at $\approx 1 \times 10^{2} \mathrm{CFU}$ per blossom. The temporal population dynamics of AAC8-1ST were monitored by sampling blossoms at $0,12,24,48,72$, and $96 \mathrm{~h}$ after inoculation, macerating the tissues in $1 \mathrm{ml}$ of PBS, and spreading 10-fold serial dilutions of the macerate evenly onto NA plates amended with kanamycin $(100 \mu \mathrm{g} / \mathrm{ml})$. Plates were incubated at $30^{\circ} \mathrm{C}$ for $36 \mathrm{~h}$ and the colonies were enumerated. To ensure that only A. avenae subsp. citrulli colonies were counted, plates were illuminated with ultraviolet light to visualize the GFP phenotype. Each treatment was replicated on 10 blossoms and the average number of $A$. avenae subsp. citrulli $\mathrm{CFU}$ recovered from each blossom was transformed $\left(\log _{10}[\mathrm{CFU}+1]\right)(5)$ and plotted against time to compare the effects of the blossom treatments on blossom colonization.

Effects of blossom protection on watermelon seed infestation by $A$. avenae subsp. citrulli. To assess the efficacy of blossom protection to prevent seed infection by A. avenae subsp. citrulli, watermelon plants (cv. Crimson Sweet) were established under greenhouse conditions and, at anthesis, 10 blossoms, each on a separate plant, were pollinated and treated with either AAA 99-2, P. fluorescens A506, or WS- 1 at $\approx 1 \times 10^{8}$ CFU/blossom, as described previously. Additionally, blossoms were inoculated with $10 \mu \mathrm{l}$ of PBS and $10 \mu \mathrm{l}$ of Kocide $101(0.4 \% \mathrm{wt} / \mathrm{vol})$ as positive and negative controls, respectively. Five hours after protection, each blossom was challenged with $A$. avenae subsp. citrulli AAC94-48 (wild type) (31) at $\approx 1 \times 10^{9} \mathrm{CFU} /$ blossom. Blossoms were allowed to develop for 35 day and, at maturity, seed were extracted manually without rinsing. To prevent cross-contamination, prior to seed extraction, each fruit was surface sterilized with $0.5 \% \mathrm{NaOCl}$. Additionally, knives and other tools used in seed extraction were surface sterilized between fruit. Seed from each fruit were maintained as individual lots and, after air-drying overnight at $25^{\circ} \mathrm{C}$, they were stored in paper bags at $5^{\circ} \mathrm{C}$ until they were tested. Seed samples from each lot $(n=100$ seeds) were tested for A. avenae subsp. citrulli by the seedling grow-out assay as described previously. For each sample, seed germination data also were collected daily for 14 days. This experiment was re- peated three times and ANOVA was used to test the significance of the effect of blossom protection on seed infestation and seed germination. Additionally, Fisher's LSD test was employed to compare the effects of the blossom treatments on the mean seed germination and percent seed lot infestation.

\section{RESULTS}

Characterization of biological control candidates. From a total of 30 candidates, 3 bacteria were identified with in vivo antagonistic activity against $A$. avenae subsp. citrulli. These included A. avenae subsp. avenae (AAA 99-2), a pathogen of maize; P. fluorescens A506, the biocontrol agent in the commercially available product BlightBan A506 (34); and WS-1, a grampositive bacterium, tentatively identified as a Brevibacterium sp. based on substrate utilization analysis by BIOLOG (similarity index value of 0.33 ). In vivo assays indicated that the biocontrol activity of WS-1 was not significantly better than PBS; therefore, full characterization of this strain was not completed. In the in vitro screens, AAA 99-2 produced inhibition zones that were $\approx 1 \mathrm{~cm}$ in diameter on KMB and nutrient agar (Fig. 1). In contrast, the zones of inhibition produced by WS-1 and $P$. fluorescens A506 were larger in diameter $(\approx 2 \mathrm{~cm})$ on $\mathrm{KMB}$. Although similar zones of inhibition were produced by WS-1, P. fluorescens A506 failed to limit $A$. avenae subsp. citrulli growth on NA.

Efficacy of biological control seed treatments under growth chamber conditions. Seed harvested from watermelon fruit in a natural BFB outbreak in Dodge County, GA in 2003 were found to be heavily infested with $A$. avenae subsp. citrulli by IMS-PCR and the seedling grow-out assay. The level of BFB seedling transmission observed for this lot was $\approx 63 \%$. When applied to naturally infested watermelon seed, the biocontrol agents delayed the onset of BFB seedling transmission relative to PBS (Fig. 2A). For PBS-treated seed, mean BFB incidence was $16 \% 5$ days after planting and, by day $15,96.5 \%$ of the seedlings were symptomatic. Seed treatments with WS-1 and P. fluorescens A506 delayed BFB onset by 2 days and reduced final BFB seedling transmission by 11.9 and $38.0 \%$, respectively. AAA $99-2$ displayed the highest level of disease suppression, delaying BFB onset by 12 days and limiting seedling transmission to $3.4 \%$, which represents a $97 \%$ reduction in disease transmission relative to PBStreated seed. ANOVA conducted on BFB AUDPC values indicated that the effect of experiment was not significant $(P=0.22)$; hence, data from the different experiments were pooled and analyzed. The effects of the biocontrol seed treatments were significant $(P=0.012)$ and Fisher's LSD analysis indicated that BFB transmission for WS-1-treated seed $(85.0 \%)$ was not significantly different from the positive control (PBS) (Fig. 2B). The difference in AUDPC values for WS-1- and P. fluorescens A506-treated seed was not significant, but seed treatment with P. fluorescens A506 resulted in significantly less BFB transmission than PBS. Overall, seed treatment with AAA 99-2 resulted in the greatest suppression of BFB transmission (AUDPC $=20.27$ ) but this was not significantly different from $P$. fluorescens A506.

Efficacy of biocontrol seed treatments under greenhouse conditions. In general, the levels of BFB seed transmission observed in the greenhouse experiments were lower than those observed in the growth chambers (germination boxes). This was expected because greenhouse conditions were less conducive to BFB development, with greater fluctuations in temperature and $\mathrm{RH}$ (data not shown). The highest levels of BFB transmission were observed for PBS-treated seed (6.5 and $4.1 \%$ for experiments 2 and 3, respectively). In experiment $1 \mathrm{BFB}$ transmission for $P$. fluorescens A506-treated seed (16.6\%) was higher than for PBS-treated seed $(9.8 \%)$. As in the growth-chamber study, AAA 99-2-treated watermelon seed developed symptoms later (delayed by 2 days) and displayed the lowest levels of BFB incidence at the end of the experiment (Fig. 3A and B, data for experiment 2 
only). Similar trends were observed for experiments 1 and 3; however, in the third experiment, unusually low levels of BFB transmission were observed (data not shown). ANOVA of the AUDPC data indicated that the effects of experiment were significant $(P=0.001)$; hence, the experiments were analyzed separately. In all experiments, seed treated with AAA 99-2 resulted in the lowest levels of BFB transmission, but this was not significantly different from seed treated with $P$. fluorescens A506. The mean seedling emergence was 93.0, 92.1, 91.8, and 92.9\% for watermelon seed treated with AAA 99-2, P. fluorescens A506, Kocide, and PBS, respectively. Seedling emergence was not influenced by the seed treatments $(P=0.27)$.

Effects of biocontrol agents on $A$. avenae subsp. citrulli colonization of female watermelon blossoms. In female watermelon blossoms pretreated with $10 \mu \mathrm{l}$ of PBS, A. avenae subsp. citrulli AAC8-1ST populations increased from $\approx 3.7 \times 10^{2} \mathrm{CFU}$ per blossom to $\approx 4.2 \times 10^{6} \mathrm{CFU} /$ blossom by $96 \mathrm{~h}$ postinoculation (Fig. 4). In contrast, AAC8-1ST populations rapidly declined in blossoms treated with Kocide, AAA 99-2, and P. fluorescens
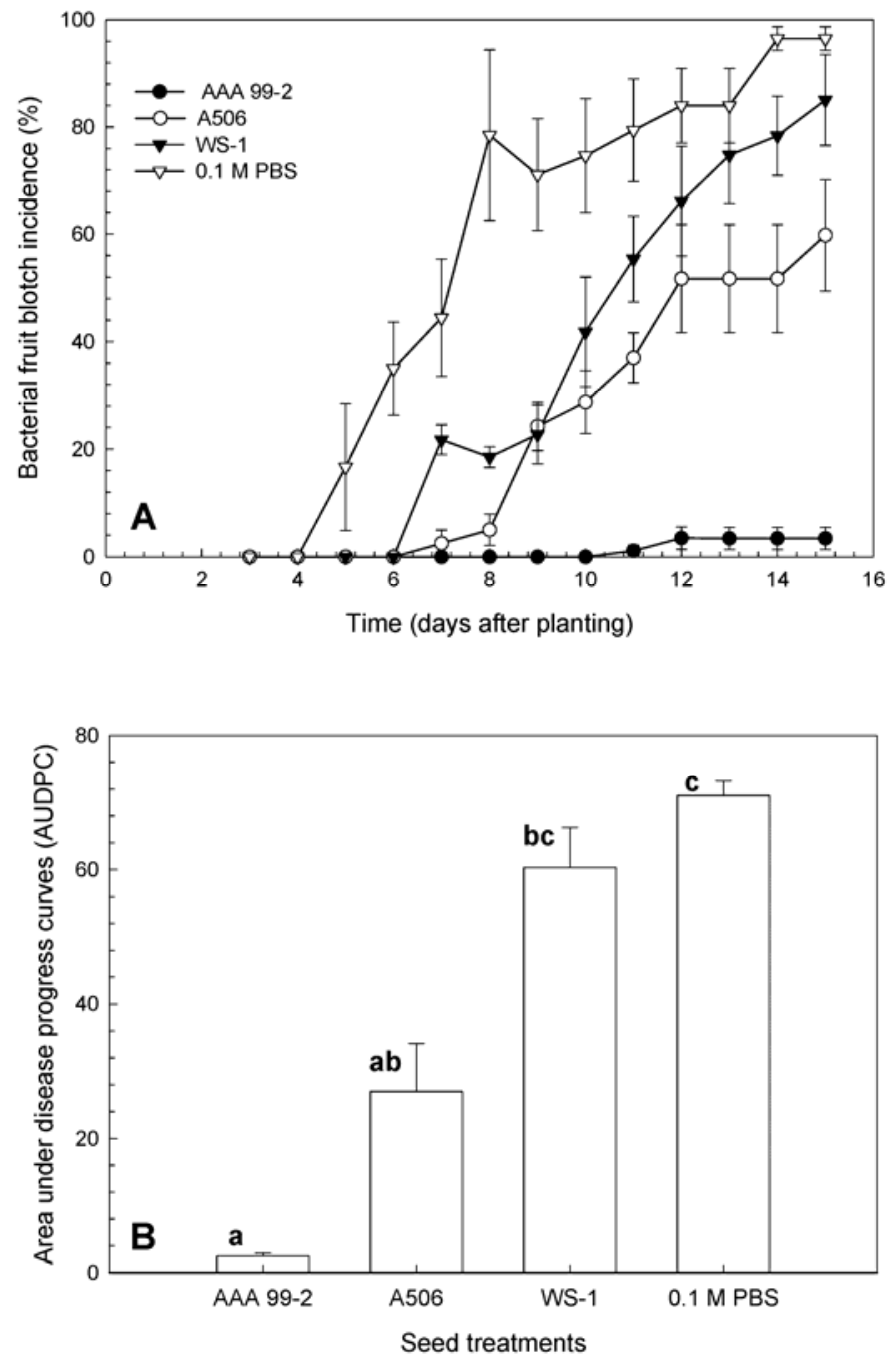

Fig. 2. A, Effects of biological control seed treatments on bacterial fruit blotch (BFB) seedling transmission for watermelon (cv. Crimson Sweet) seed under conditions of $100 \%$ relative humidity and $30^{\circ} \mathrm{C}$. Each data point represents the mean BFB seedling transmission for 12 seed lots (four replicates, $n=25$ seed, in three experiments) and lines indicate the standard error of the means. B, Bar chart of the area under the disease progress curves (AUDPC) calculated for BFB seedling transmission for seed treated with biological control agents and $0.1 \mathrm{M}$ phosphate buffered saline. Bars indicate the mean AUDPC values and lines indicate the standard errors of the means. Treatments with different letters are significantly different according to Fisher's test of least significant difference $(P<0.05)$
A506. This decline was most rapid for female blossoms treated with Kocide and after $24 \mathrm{~h}$, the bacterium could not be recovered. Reductions in AAC8-1ST populations were faster for blossoms treated with $P$. fluorescens A506 than for AAA 99-2. At 24 h after inoculation, mean AAC8-1ST populations were 6.5 and $21.5 \mathrm{CFU}$ per blossom for blossoms treated with $P$. fluorescens A506 and AAA 99-2, respectively. By $48 \mathrm{~h}$ after inoculation, AAC8-1ST could not be recovered from blossoms treated with either bacterium.

Effects of blossom protection on A. avenae subsp. citrulli seed infestation. Of 136 watermelon fruit produced from blossoms protected and subsequently inoculated with $A$. avenae subsp. citrulli, none developed visible BFB symptoms. In experiment 3, conducted in June 2004, 100\% of the Kocide-treated blossoms aborted and no fruit were produced. ANOVA of seed lot infestation data indicated that the effect of experiment was not significant $(P=0.90)$; hence, the data for the three experiments were combined and analyzed. Overall, 63\% (17/27) of the seed lots from PBS-treated blossoms were infested with A. avenae
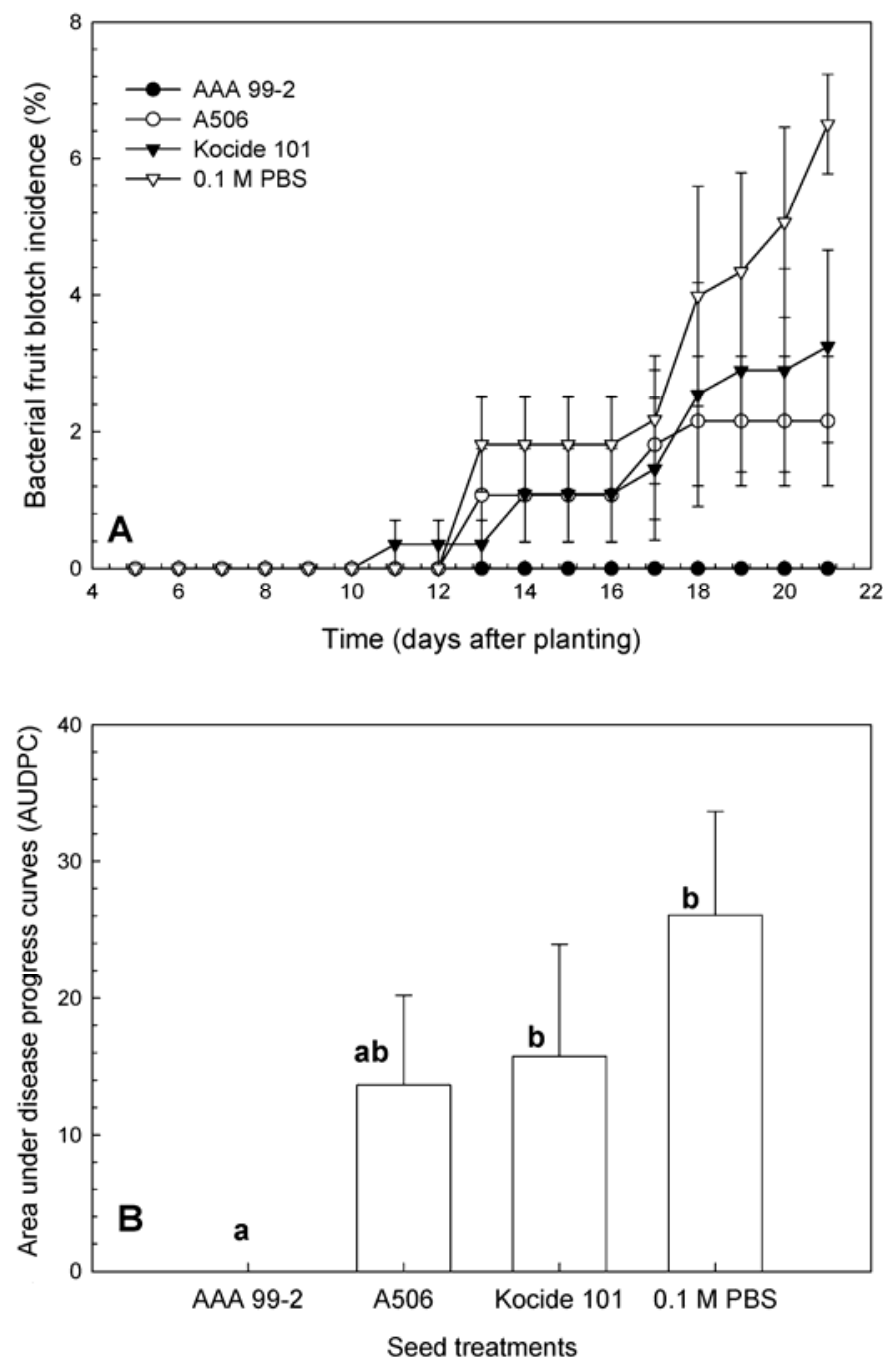

Fig. 3. A, Effects of chemical and biological seed treatments on bacterial fruit blotch (BFB) seedling transmission for watermelon (cv. Crimson Sweet) seed over time under greenhouse conditions for one experiment (experiment 2). Each data point represents the mean of four replicates $(n=72$ seed $)$ and the lines indicate the standard error of the means. B, Bar chart of the area under the disease progress curves (AUDPC) calculated for BFB seedling transmission for seed treated with biological control agents and Kocide and $0.1 \mathrm{M}$ phosphate buffered saline as negative and positive controls, respectively. Bars indicate the mean AUDPC values and lines indicate the standard error of the means. Treatments with different letters are significantly different according to Fisher's test of least significant difference $(P<0.05)$. 
subsp. citrulli (Fig. 5). For seed lots from blossoms protected with Kocide, P. fluorescens A506, and AAA 99-2, the levels of seed infestation were 21.1 (4/19), 24.1 (7/29), and 13.8\% (4/29), respectively. The effect of blossom treatment on seed lot infestation was statistically significant $(P=0.0002)$ and Fisher's LSD analysis indicated that $A$. avenae subsp. citrulli infestation in seed lots from WS-1-treated blossoms (48.3\%) was not significantly different from seed lots from blossoms treated with PBS. The level of A. avenae subsp. citrulli infestation for seed lots from blossoms treated with WS-1 was not significantly different from seed lots from blossoms treated with $P$. fluorescens A506. The proportions of $A$. avenae subsp. citrulli-infested seed lots from blossoms protected with AAA 99-2 and Kocide were significantly lower than for all other treatments.

The effect of blossom protection on watermelon seed germination was statistically significant $(P=0.0006)$. The mean germination percentage for seed lots from blossoms protected with Kocide was the lowest of all treatments $(74.33 \%)$ (Fig. 5), whereas those from blossoms treated with AAA 99-2 displayed the highest germination $(90.84 \%)$. ANOVA indicated that the effect of experiment was significant $(P=0.02)$ and experiment 2 was significantly different than experiments 1 and 3 . Hence, data from experiment 2 were analyzed separately. In experiment 2, mean germination percentage for seed from AAA 99-2-treated blossoms $(88.3 \%)$ was significantly higher than for seed from PBS-treated blossoms (66.8\%), but was not different than those from blossoms treated with P. fluorescens A506 (84.4\%), WS-1 (72.7\%), or Kocide $(74.6 \%)$. Analysis of the pooled data from experiments 1 and 3 showed that mean germination percentage for seed from AAA 99-2-treated blossoms (90.8\%) was significantly higher than for seed from blossoms treated with Kocide. Germination percentages for seed from blossoms protected with $P$. fluorescens A506 (86.73\%), WS-1 (84.89\%), and PBS (83.11\%) were not significantly different from each other but were significantly higher than for seed from Kocide-treated blossoms (74.33\%).

\section{DISCUSSION}

Through preliminary screens, we identified three potential biocontrol candidates with in vitro antagonistic activity against A. avenae subsp. citrulli. Unlike AAA 99-2 and WS-1, $P$. fluorescens A506 inhibited the growth of A. avenae subsp. citrulli on KMB but not on NA. Under iron-limiting conditions, rhizobac-

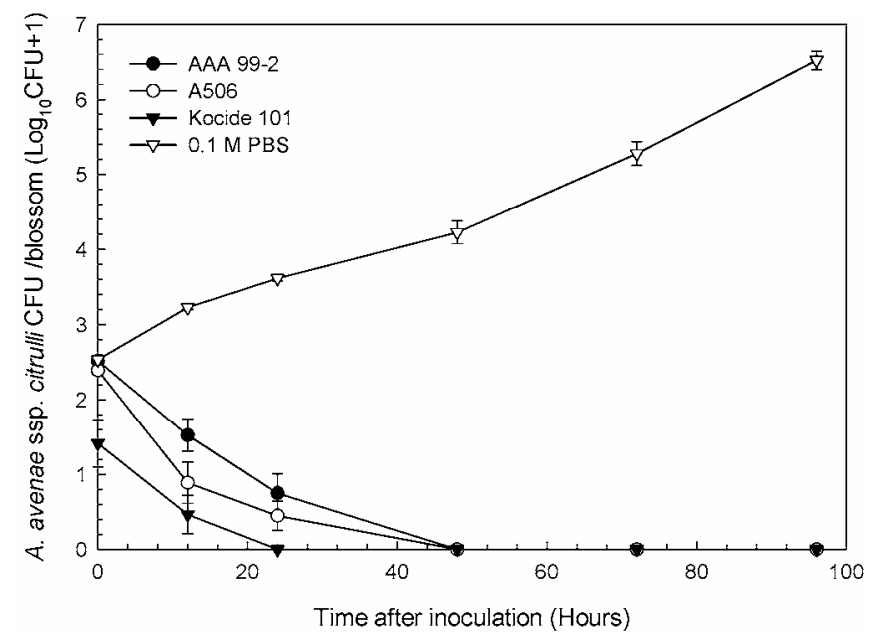

Fig. 4. Population dynamics of Acidovorax avenae subsp. citrulli AAC8-1ST on female watermelon blossoms (cv. Crimson Sweet) protected with A. avenae subsp. avenae AAA 99-2, Pseudomonas fluorescens A506, and a grampositive bacterium, tentatively identified as a Brevibacterium sp. Each data point represents the mean A. avenae subsp. citrulli population for 10 blossoms and the lines represent the standard error of the means. teria, such as fluorescent pseudomonads and Agrobacterium spp., produce a range of iron-chelating compounds or siderophores that are involved in the biological control of soilborne fungal diseases $(22,23)$. We speculate that siderophore production by $P$. fluorescens A506 may be partially responsible for biocontrol of A. avenae subsp. citrulli. On the other hand, the mode of action for AAA 992 is unknown. It is well established that biological control of plant diseases involves effective competition for nutrients and colonization sites, production of antimicrobial compounds, and induction of plant resistance $(3,13,15)$. It is possible that the antagonism displayed by AAA 99-2 could be due to antibiosis-related competition as described for the interaction between E. herbicola and E. amylovora, the fire blight pathogen (33). Wilson et al. suggested that preemptive and competitive colonization of stigmatic surfaces by $E$. herbicola reduced the rate of colonization by E. amylovora (33). Detailed knowledge of the biological control mechanisms underlying the interaction between $A$. avenae subsp. avenae AAA 99-2 and A. avenae subsp. citrulli may lead to the development of enhanced biocontrol-based BFB management strategies.

Watermelon seed treatment with AAA 99-2 displayed superior suppression of BFB transmission under growth chamber conditions, limiting seedling transmission to less than $3.5 \%$. However, under greenhouse conditions, unexpectedly low levels of BFB transmission were observed. It is likely that the low levels of BFB transmission were due to environmental conditions that were unfavorable for symptom development, even though seedlings were incubated under plastic chambers. As a result, it was difficult to demonstrate the same level of biological control efficacy observed in the seedling grow-out assays conducted in germination boxes. Mercier and Lindow suggested that high disease pressure is necessary to evaluate biocontrol activity and speculated that an antagonist that inhibits E. amylovora growth on detached blossoms in a controlled laboratory assay may not perform equally under more variable conditions (19). In our case, BFB transmission studies conducted in germination boxes represent a more stringent, "worst-case" scenario, and the fact that AAA 99-2 restricted BFB transmission under these conditions suggests that it has potential as a seed treatment.

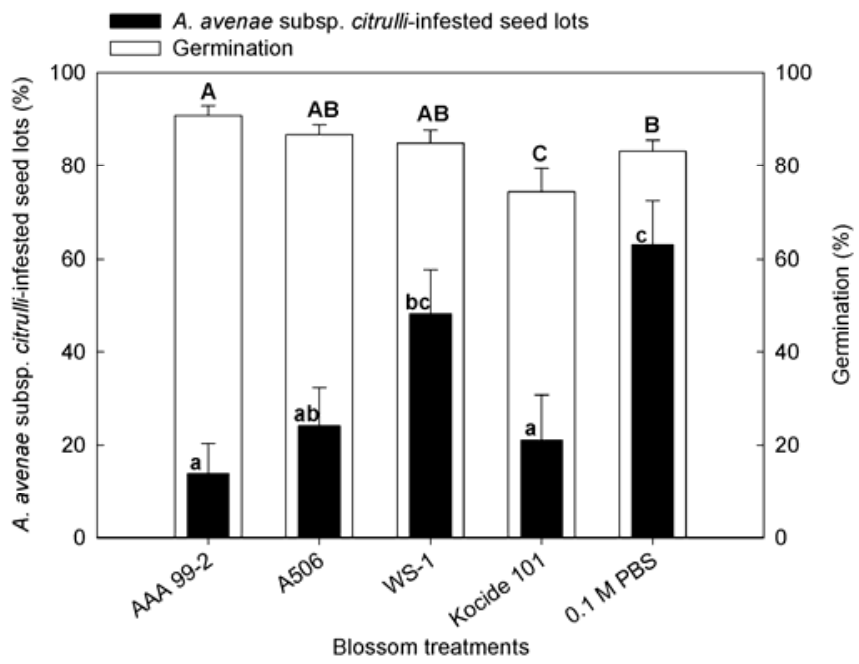

Fig. 5. Effects of female watermelon blossom protection with chemical and biological control agents on seed lot infestation by Acidovorax avenae subsp. citrulli and seed germination. Bars indicate the mean percentage of infested seed lots and mean germination, and the lines indicate the standard error of the means. Treatments with the same letters are not significantly different according to Fisher's test of least significant difference (LSD) $(P<0.05)$. Uppercase letters represent the results of Fisher's LSD for comparing the effects of blossom treatments on germination and lowercase letters represent the comparison of the effects of blossom treatments on bacterial fruit blotch seedling transmission. 
In one of three experiments, BFB transmission for Kocide-treated seed was not different from PBS-treated seed. The ineffectiveness of Kocide could be explained by the possibility that active copper ions may have been inactivated prior to seedling emergence. Furthermore, it is possible that bacteria present on or in the seed may have been shielded from copper ions during seed treatment, allowing them to escape and subsequently infect the seedlings. For this reason, Kocide may not be efficacious as a seed treatment for BFB and is not used routinely on cucurbit seed. Another potential problem is the phytotoxicity of Kocide to watermelon and other cucurbit seedlings. Such phytotoxic effects were reported when copper sulfate was applied to control seedborne pathogens of lettuce (4). Finally, the development of copper tolerance has been reported for several gram-negative phytopathogenic bacteria, including $A$. avenae subsp. citrulli $(1,2,28)$. This fact limits the long-term utility of copper as a management tool and makes the development of biocontrol seed treatments more attractive.

Population dynamics studies on attached watermelon blossoms demonstrated that $A$. avenae subsp. citrulli can rapidly colonize stigmatic surfaces. It is possible that the blossoms protect bacteria from stressful environmental conditions and provide nutrition for population growth. The in vivo blossom studies provided evidence that Kocide and biocontrol agents can suppress epiphytic A. avenae subsp. citrulli growth when applied $5 \mathrm{~h}$ prior to inoculation. Similar findings were reported for E. amylovora on pear blossoms treated with P. fluorescens A506 24 h prior to challenge (34). As expected, Kocide was the most effective blossom protectant because, as a contact bactericide, it probably killed A. avenae subsp. citrulli cells immediately after they were applied to the stigma. Unfortunately, Kocide may not be appropriate for blossom protection, because we observed phytotoxicity in the form of stigma necrosis that led to unusually high levels of fruit abortion at elevated temperatures. Hence, although Kocide showed the best activity against $A$. avenae subsp. citrulli growth on watermelon blossoms, it is unlikely that, at the rate tested, it can be used for watermelon blossom protection. Fortunately, data from the attached blossom protection study demonstrated that biological control also can limit epiphytic A. avenae subsp. citrulli population growth.

In this study, we demonstrated that biocontrol agents applied to watermelon blossoms M17 significantly reduce A. avenae subsp. citrulli seed infestation relative to PBS. In experiment 1, blossom treatments with AAA 99-2 and P. fluorescens A506 completely prevented seed infestation. The inability to prevent seed infestation in experiments 2 and 3 possibly could be explained by incomplete coverage of the stigma during application, since the antagonists were applied in liquid suspension. Additionally, we challenged blossoms with high concentrations of the pathogen $\left(\approx 1 \times 10^{9} \mathrm{CFU} / \mathrm{blossom}\right)$ that would not be expected to occur in asymptomatic tissues under natural conditions. We also omitted the fermentation and rinsing steps that usually are included in commercial seed processing. In so doing, we may have underestimated the potential of biological control blossom protection to prevent seed infection by A. avenae subsp. citrulli. Finally, it may be possible that selecting biocontrol agents with more effective modes of antagonism or developing more effective blossom inoculation strategies (e.g., lyophilization of biocontrol agents) may result in better control. These strategies can be explored in future attempts to field test the blossom protection strategy.

It is important to note that, similar to the currently employed seed treatments, biocontrol blossom protection reduced but failed to prevent A. avenae subsp. citrulli seed infestation and BFB seedling transmission. As stated earlier, this is undesirable because there is zero tolerance for the pathogen in seed and transplant production systems. However, if biocontrol blossom protection is combined with commercial seed processing practices and compatible pre- and postharvest management strategies, better results could be obtained.
Another benefit of blossom protection with AAA 99-2 was a significant increase in seed germination. Similar improvements in germination with biological control seed treatments were reported previously $(10,18,20)$. Interestingly, improvements in seedling emergence were not observed when the biocontrol agents were applied directly to infested seed. This observation suggests that the biocontrol agents may not only be protecting the blossoms from A. avenae subsp. citrulli colonization but they also may be influencing seed development within the ovaries. This may be possible because Pantoea ananatis, a nonpathogen on watermelon, was able to penetrate blossoms and infest seed (30). In similar fashion, AAA 99-2 might be gaining access to and improving seed physiology. Further investigation is needed to better explain this phenomenon.

Data presented in this report indicate great potential for biological control of BFB with AAA 99-2. The results suggest that it may be beneficial to further evaluate the efficacy of biological control of BFB under commercial seed production conditions. The blossom protection approach is particularly attractive because, in hybrid seed production, it can be applied during manual pollination, which would not require extra operational steps. Lyophilized cells of the biocontrol agents could be mixed with pollen to make it easier for seed producers to store and deliver the biocontrol inoculum. It is necessary to protect watermelon blossoms only for the $24 \mathrm{~h}$ that they normally are open; therefore, the likelihood of success for this strategy is good.

Despite its performance as a biocontrol agent in this study, AAA 99-2 is pathogenic to maize and could not be used in its current state as a commercial biocontrol agent. Although it may be possible to mutagenize AAA 99-2 through exhaustive screens to eliminate pathogenicity, it also may be possible to find nonpathogenic biocontrol candidates with equal or superior antagonistic activity against $A$. avenae subsp. citrulli.

To our knowledge, this is the first study that provides evidence that biological control blossom protection could reduce watermelon seed infestation by A. avenae subsp. citrulli. This strategy is based on the assumption that blossom invasion is important for seed infestation under natural conditions. However, although blossom inoculation leads to seed infestation, it still is necessary to verify the epidemiological significance of this phenomenon.

\section{ACKNOWLEDGMENTS}

This work was supported by a USDA CSREES S-IPM Grant entitled "Bacterial fruit blotch management by biological control of seed infection.” We thank J. Lessl, S. Lessl, and F. Medieros for technical input; P. Ojiambo for assistance with statistical analysis; and S. Lindow, M. Schell, R. Stall, and R. Gitaitis for providing bacterial strains.

\section{LITERATURE CITED}

1. Alexander, S. A., Kim, S. H., and Waldenmaier, C. M. 1999. First report of copper-tolerant Pseudomonas syringae pv. tomato in Virginia. Plant Dis. 83:964.

2. Bender, C. L., and Cooksey, D. A. 1986. Indigenous plasmids in Pseudomonas syringae pv. tomato-Conjugative transfer and role in copper resistance. J. Bacteriol. 165:534-541.

3. Bloemberg, G. V., and Lugtenberg, B. J. J. 2001. Molecular basis of plant growth promotion and biocontrol by rhizobacteria. Curr. Opin. Plant Biol. 4:343-350.

4. Carisse, O., Ouimet, A., Toussaint, V., and Philion, V. 2000. Evaluation of the effect of seed treatments, bactericides, and cultivars on bacterial leaf spot of lettuce caused by Xanthomonas campestris pv. vitians. Plant Dis. 84:295-299.

5. Gomez, K. A., and Gomez, A. A. 1984. Statistical Procedures for Agricultural Research. John Wiley and Sons, New York.

6. Gupta, C. P., Dubey, R. C., and Maheshwari, D. K. 2002. Plant growth enhancement and suppression of Macrophomina phaseolina causing charcoal rot of peanut by fluorescent Pseudomonas. Biol. Fertil. Soils 35:399-405.

7. Hopkins, D. L., Cucuzza, J. D., and Watterson, J. C. 1996. Wet seed treatments for the control of bacterial fruit blotch of watermelon. Plant Dis. 80:529-532. 
8. Hopkins, D. L., and Thompson, C. M. 2002. Seed transmission of Acidovorax avenae subsp. citrulli in cucurbits. Hortscience 37:924-926.

9. Hopkins, D. L., Thompson, C. M., Hilgren, J., and Lovic, B. 2003. Wet seed treatment with peroxyacetic acid for the control of bacterial fruit blotch and other seedborne diseases of watermelon. Plant Dis. 87:14951499.

10. Jensen, B., Knudsen, I. M. B., Madsen, M., and Jensen, D. F. 2004. Biopriming of infected carrot seed with an antagonist, Clonostachys rosea, selected for control of seedborne Alternaria spp. Phytopathology 94:551-560.

11. Johnson, K. B., and Stockwell, V. O. 1998. Management of fire blight: A case study in microbial ecology. Annu. Rev. Phytopathol. 36:227-248.

12. Kang, Y. W., Carlson, R., Tharpe, W., and Schell, M. A. 1998. Characterization of genes involved in biosynthesis of a novel antibiotic from Burkholderia cepacia $\mathrm{BC} 11$ and their role in biological control of Rhizoctonia solani. Appl. Environ. Microbiol. 64:3939-3947.

13. Keel, C., and Defago, G. 1997. Interactions between beneficial soil bacteria and root pathogens: Mechanisms and ecological impacts. Pages 27-46 in: Multitrophic Interactions in Terrestrial Systems. A. C. Gange and V. K. Brown, eds. Blackwell Science, London.

14. King, E. O., Ward, M. K., and Raney, D. E. 1956. Two simple media for the demonstration of pyocyanin and fluorescin. J. Lab. Clin. Med. 44:301-307.

15. Landa, B. B., Mavrodi, O. V., Raaijmakers, J. M., Gardener, B. B. M., Thomashow, L. S., and Weller, D. M. 2002. Differential ability of genotypes of 2,4-diacetylphloroglucinol-producing Pseudomonas fluorescens strains to colonize the roots of pea plants. Appl. Environ. Microbiol. 68:3226-3237.

16. Latin, R. X., and Hopkins, D. L. 1995. Bacterial fruit blotch of watermelon: The hypothetical exam question becomes reality. Plant Dis. 79:761-765.

17. Lindow, S. E., McGourty, G., and Elkins, R. 1996. Interactions of antibiotics with Pseudomonas fluorescens strain A506 in the control of fire blight and frost injury to pear. Phytopathology 86:841-848.

18. Mao, W., Lewis, J. A., Hebbar, P. K., and Lumsden, R. D. 1997. Seed treatment with a fungal or a bacterial antagonist for reducing corn dampingoff caused by species of Pythium and Fusarium. Plant Dis. 81:450-454.

19. Mercier, J., and Lindow, S. E. 2001. Field performance of antagonistic bacteria identified in a novel laboratory assay for biological control of fire blight of pear. Biol. Control 22:66-71.

20. Mew, T. W., Cottyn, B., Pamplona, R., Barrios, H., Li, X. M., Chen, Z. Y., Lu, F., Nilpanit, N., Arunyanart, P., Kim, P. V., and Du, P. V. 2004. Applying rice seed-associated antagonistic bacteria to manage rice sheath blight in developing countries. Plant Dis. 88:557-564.

21. Norelli, J. L., Jones, A. L., and Aldwinckle, H. S. 2003. Fire blight management in the twenty-first century-Using new technologies that enhance host resistance in apple. Plant Dis. 87:756-765.
22. O'Sullivan, D. J., and O'Gara, F. 1992. Traits of fluorescent Pseudomonas spp. involved in suppression of plant root pathogens. Microbiol. Rev. 56:662-676.

23. Penyalver, R., Oger, P., Lopez, M. M., and Farrand, S. K. 2001. Ironbinding compounds from Agrobacterium spp.: Biological control strain Agrobacterium rhizogenes K84 produces a hydroxamate siderophore. Appl. Environ. Microbiol. 67:654-664.

24. Schaad, N. W., Postnikova, E., and Randhawa, P. 2003. Emergence of Acidovorax avenae subsp. citrulli as a crop-threatening disease of watermelon and melon. Pages 573-581 in: Presentations 6th Int. Conf. Pseudomonas syringae pathovars and related pathogens. N. W. Schaad, ed. Kluwver Press, Maratea, Italy.

25. Schaad, N. W., Sowell, G., Goth, R. W., Colwell, R. R., and Webb, R. E. 1978. Pseudomonas pseudoalcaligenes subsp. citrulli subsp. nov. Int. J. Syst. Bact. 28:117-125.

26. Somodi, G. C., Jones, J. B., Hopkins, D. L., Stall, R. E., Kucharek, T. A., Hodge, N. C., and Watterson, J. C. 1991. Occurrence of a bacterial watermelon fruit blotch in Florida. Plant Dis. 75:1053-1056.

27. Sowell, G., and Schaad, N. W. 1979. Pseudomonas pseudoalcaligenes subsp. citrulli on watermelon-Seed transmission and resistance of plant introductions. Plant Dis. 63:437-441.

28. Walcott, R. R., Fessehaie, A., and Castro, A. C. 2004. Differences in pathogenicity between two genetically distinct groups of Acidovorax avenae subsp. citrulli on cucurbit hosts. J. Phytopathol. 152:277-285.

29. Walcott, R. R., and Gitaitis, R. D. 2000. Detection of Acidovorax avenae subsp. citrulli in watermelon seed using immunomagnetic separation and the polymerase chain reaction. Plant Dis. 84:470-474.

30. Walcott, R. R., Gitaitis, R. D., and Castro, A. C. 2003. Role of blossoms in watermelon seed infestation by Acidovorax avenae subsp. citrulli. Phytopathology 93:528-534.

31. Walcott, R. R., Langston, D. B., Sanders, F. H., and Gitaitis, R. D. 2000. Investigating intraspecific variation of Acidovorax avenae subsp. citrulli using DNA fingerprinting and whole cell fatty acid analysis. Phytopathology 90:191-196.

32. Willems, A., Goor, M., Thielemans, S., Gillis, M., Kersters, K., Ley, J. D., and De Ley, J. 1992. Transfer of several phytopathogenic Pseudomonas species to Acidovorax as Acidovorax avenae subsp. avenae subsp. nov., comb. nov., Acidovorax avenae subsp. citrulli, Acidovorax avenae subsp. cattleyae, and Acidovorax konjaci. Int. J. Syst. Bact. 42:107-119.

33. Wilson, M., Epton, H. A. S., and Sigee, D. C. 1992. Interactions between Erwinia herbicola and E. amylovora on the stigma of hawthorn blossoms. Phytopathology 82:914-918.

34. Wilson, M., and Lindow, S. E. 1993. Interactions between the biological control agent Pseudomonas fluorescens A506 and Erwinia amylovora in pear blossoms. Phytopathology 83:117-123. 